\title{
Moses
}

\section{Freud's ultimate project}

\author{
RISTO OLAVI NURMELA
}

$M$ oses and Monotheism was the last work of Sigmund Freud, known as the founder of psychoanalysis. It is not a study of psychoanalytical issues, but mainly a study of the biblical figure Moses, albeit with psychoanalytical applications. Freud attempted to prove that Moses' original monotheistic religion, which he, an Egyptian, gave to the Israelites, was one without sacrifices and priests, whereas the Israelite religion known from the Bible was not even strictly monotheistic. Moses' religion, according to Freud, was the religion of Ikhnaton, the similarity of which to Israelite religion Freud was in fact among the first to realize. The religion of Moses, which Freud thought he was able to reconstruct, was in my view actually Judaism, which later developed from Israelite religion. Freud was a stern atheist, but nevertheless also an uncompromising Jew, who never thought atheism would exclude Jewishness. As such he stands as a fine example of Judaism being something more and other than religion and ethnicity. Freud worked on Moses and Monotheism during his five last years. What apparently motivated him was Hitler's rise to power in Germany, which presented a threat to Freud personally as well as to his life's work, since the Nazis outlawed psychoanalysis. This threat became a reality when Germany occupied Austria in 1938. Freud fled to London where he finished Moses and Monotheism, published only months before his death in September 1939. In this work Freud's appreciation of Judaism finds a remarkable expression.

Presenting and developing psychoanalysis by means of various approaches in his numerous writings, Sigmund Freud also found that it could make contributions in other fields such as the arts or anthropology. Totem and Taboo was such a work, the results of which, to be sure, have not survived critical scrutiny. Totem and Taboo also purports to offer an explanation of the emergence of religion, a very sensitive topic for Freud. He was known as an atheist, which nevertheless in no way diminished his commitment to Judaism or, more properly, Jewishness. In a self-presentation written in I925 he says: 'My parents were Jews and I, too, have remained a Jew' (Freud I 948b: 34). By I 900 the Viennese Jews had the world's highest conversion rate and one-quarter of the Jews of Vienna who left Judaism declared themselves to be without religion (Berkley I 988: 54). Freud was, in fact, an outstanding example of how Judaism cannot be 
labelled simply as a religion: faith in God is not prerequisite for being a Jew in another sense than ethnically.

Freud's clearest exposition of his atheism was The Future of an Illusion, written in 1927 (Freud I948b: 325-380), in which he vehemently declared religion to be worthless. Nevertheless, in a postscript to the self-presentation quoted above, added in I 93 I, he wrote: 'In "The Future of an Illusion" I esteemed religion mainly negatively; later I found the formula which accords it more justice: its power depends certainly on its truth content, but this truth is not a material but a historical one' (Freud r 950: 33).

One is left wondering what Freud meant by 'historical truth'. The answer to this question is given in the conclusion of Moses and Monotheism: 'I too should credit the believer's solution with containing the truth; it is not, however, the material truth, but an historical truth.... I do not believe that one supreme great God "exists" to-day, but I believe that in primæval times there was one person who must appear gigantic and who, raised to the status of a deity, returned to the memory of men' (Freud 2010: 204).

As for this insight, Freud referred to Totem and Taboo, published in I9I2. The religious phenomena are 'to be understood only on the model of the neurotic symptoms of the individual, which are so familiar to us, as a return of long forgotten important happenings in the primæval history of the human family, that they owe their obsessive character to that very origin and therefore derive their effect on mankind from the historical truth they contain' (Freud 2010: 94).

In a letter to Max Eitington Freud wrote that Moses and Monotheism differed from The Future of an Illusion in admitting that religion was not merely illusion but also had 'an historical kernel of truth, which explains its great effectiveness' (Freud and Eitington 2004: 883).

More astonishing, when The Future of an Illusion still was being printed, Freud wrote to Sándor Ferenczi that he found the book 'childish'; '...fundamentally I think differently, consider this work analytically feeble and insufficient as a self-confession' (Freud and Ferenczi 2005: I64), and to Eitington: '... the analytical content of the work is very tiny and it is otherwise, too, of little esteem' (Freud and Eitington 2001: 562). Moreover, in a letter to Oskar Pfister, a psychoanalyst who was a minister in the Swiss Reformed Church, Freud says that the views he has presented in the writing do not constitute any element of the doctrinal system of psychoanalysis (Freud and Pfister r 963: r 26). When working on it he once remarked to Eitington: 'It nevertheless remains to consider whether the analysis [viz. psychoanalysis] by itself [Freud's emphasis] really must result in giving up religion' (Freud and Eitington 2004: 5 I9). 
An interesting detail is that in 1928 the printing of a Russian translation was blocked by the censor in the Soviet Union (ibid. 606).

As for Jewishness, Freud asked in a 1925 article entitled 'On the resistance against psychoanalysis' whether the fact that he was a Jew who never wished to conceal his Jewishness had contributed to the hostility shown towards psychoanalysis. He concluded: 'Maybe it is not a mere coincidence that the first representative of psychoanalysis was a Jew. To confess one's faith in it a good deal of readiness to bear the fate of loneliness in the opposition was demanded, a fate which the Jew is more familiar with than someone else' (Freud I 948b: I Io).

In a preface to the Hebrew edition of Totem and Taboo (I930) Freud describes himself as one who does not understand 'the holy language', who is totally alienated from his paternal religion - as well as all other religions - who cannot share nationalist ideals, and nonetheless has never denied being a member of his people, has experienced his peculiarity as Jewish and does not wish to have it any other way.

If you asked him: 'What is still Jewish with you after having abandoned all these similarities with your compatriots?' he would answer: 'Still quite a lot, probably the most important thing.' But this essential he would presently not be able to express in clear words. It will surely be accessible to scholarly insight sometime later. (Freud I 948b: 569)

In a letter to the Committee of the Yiddish Scientific Institute of London Freud wrote, two days after his removal to London in 1938, 'You no doubt know that I gladly and proudly acknowledge my Jewishness though my attitude towards any religion, including ours, is critically negative' (Jones I 957: 253).

Moses and Monotheism was Freud's last piece of work. It turned out to be a prolonged project; Ernest Jones said that 'his ideas on Moses and religion ... were to engross him for the rest of his life'; 'he kept reading all the books he could find on Jewish history' (Jones I 957: 206, 2 10). In a letter to Eitington of I935 Freud says that 'Moses' has become a 'fixation' for him (Freud and Eitington 2004: 889, Freud's quotation marks). The first mention of the project is in a letter to Arnold Zweig of September 30, I934 (Freud and Zweig r 968: I02), whereas in a letter to Pfister of March 27, I937 he says he has completed it (Freud and Pfister 1963: I 57). Some weeks before the letter to Pfister, however he tells Eitington that he has completed 'a fragment which could be detached from the Moses-study' (Freud and Eitington 2004: 895). According to Jones, Freud 'conceived, and for the most part wrote, his ideas on Moses and religion' in I 934 (Jones I 957: 205-6). He was, however, reluctant to publish it, 
and decided to publish 'independently' two parts of the book in issues I and 4 of the periodical Imago in I937 (Freud 2010: 164). The concluding part, he declares in a preface written before the German annexation of Austria, he had decided to leave unpublished for the moment. He foresaw the ominous possibility of the institution of a Nazi regime in Austria, which would have meant the prohibition of psychoanalysis, as was the case in Germany (Cocks I 997: 58-7I). Freud thought that the Catholic Church was a bulwark against this threat, and as he moreover found that the contents of the remaining part would be offensive to the church, he decided to postpone publication 'until the time comes when it may safely venture into the light of day' (Freud 2010: 9I-2). This era arrived very soon, albeit not in the blissful form hoped for by Freud. After the Anschluss he could establish, in a second preface, that the protection offered by the Catholic Church turned out to be 'but a broken reed.' Freud fled to England, where he "may again speak and write - I almost said "think" - as I want or have to.' And now he dared to publish the conclusion of the project (Freud 2010: 93).

However, Freud also gives a somewhat different explanation for his unwillingness to publish the conclusion. In the letter to Zweig he wrote that the politics of Austria were under the control of a certain Pater Schmidt, who was an intimate of the Pope and 'unfortunately himself an ethnologist and scholar of religion'; a person who made no secret of how he detested psychoanalysis and particularly Freud's totem theory. According to Freud, Schmidt lay behind the abolition of the journal Rivista italiana di Psicoanalisi in Italy, and he was sure that his publications would not remain undetected by him. This could lead to the abolition of psychoanalysis in Vienna (Freud and Zweig I968: I02-3). Thus Freud feared that the Catholic Church would not only fail to protect psychoanalysis but would itself put an end to it. On the other hand, he apparently did not consider the viewpoints contained in Moses and Monotheism to be doctrinal elements of the system of psychoanalysis, as was not the case with The Future of an Illusion. In fact, in a letter to his son Ernst he named it his 'first performance as a historian, late enough!' (Freud r 960: 433)

The fact that Freud conceived and mainly wrote Moses and Monotheism in I 934 is significant, since Hitler had come to power in the previous year. Yosef Chayim Yerushalmi writes: 'For Freud, as for many others, the shock of the anti-Jewish barbarism brought the question of what it means to be a Jew to a new pitch of existential urgency, and there can be no doubt that it was this that provided the immediate impulse to the actual writing of Moses and Monotheism' (Yerushalmi i 99 I: I 5, cf. 76). Freud also wrote to Zweig: 'In the face of the new persecutions one again asks himself how the Jew emerged and why he incurred 
this immortal hate' (Freud and Zweig I968: I02). In the preface dated earlier March I 938 - and thus written before the Reichskristallnacht - he characterized the Nazi regime as an 'all but prehistoric barbarism' (Freud 2010: 90). He also seems to have considered the Nazi regime as a personal threat from the very beginning; in a letter to Ferenczi of April 2, I 933 he wrote concerning the appeal to flee from Austria: 'If they strike you dead, it is a manner of dying like anything else' (Freud and Ferenczi 2005: 303). It seems that Freud's response to the rise of National Socialism was an intensified interest in Judaism, the most prominent expression of which came to be Moses and Monotheism.

There was, however, also a more personal matter, which chronologically approximately coincided with Hitler's accession to power. In I923 Freud was struck down with jaw cancer and underwent two major operations (Jones I 957 : 99-I00). In I 926 he wrote to Henry Havelock Ellis: '... a recrudescence is after nearly three years deemed unlikely. I may have to expect some other exit from this life' (Freud I960: 368). However, in I 93 I recrudescence did take place (Freud and Zweig I968: 39; Jones I957: I67). In a letter of I93 I to Eitington Freud said that he expected death perhaps even within a couple of months (Freud and Eitington 2004: 252-3). Interestingly enough, The Future of an Illusion was thus written at the beginning of a period when there was hope of recovery. So within two years two serious threats to Freud's personal existence had entered or re-entered the stage; one concerning his existence as a Jewish citizen, another intimating the possibility of his imminent decease. These were two main constituents of the final period of his life, during which Moses and Monotheism took shape.

Nevertheless, Freud's interest in the Moses dates back to an earlier time. The r 9 I 4 essay 'The Moses of Michelangelo' can be seen to be a forerunner of his final work. Freud was a lover of Rome, where the Michelangelo's Moses is housed in the church of San Pietro in Vincoli. Many think that Michelangelo depicts Moses in the moment of realizing that the Israelites had manufactured the golden calf while he stayed on the mountain and received the tablets of the law, which he subsequently crushed at the foot of the mountain in his fury over the apostasy. Freud, however, believed that Michelangelo had depicted a Moses who has just overcome his impulse to crush the tablets (Freud r 949: I78, I98). His pondering on Moses gives him the occasion for a veritable study of the Bible, which he opens as follows: 'The passage of the Holy Scripture, in which Moses' behaviour at the scene of the golden calf is reported, reads as follows (I apologize for my anachronistic use of the translation of Luther)'... He quotes chapter 32 of Exodus, verses 7-I I, I4-20 and 30-5, thereby highlighting the findings of modern biblical criticism - without, however, referring to any work 


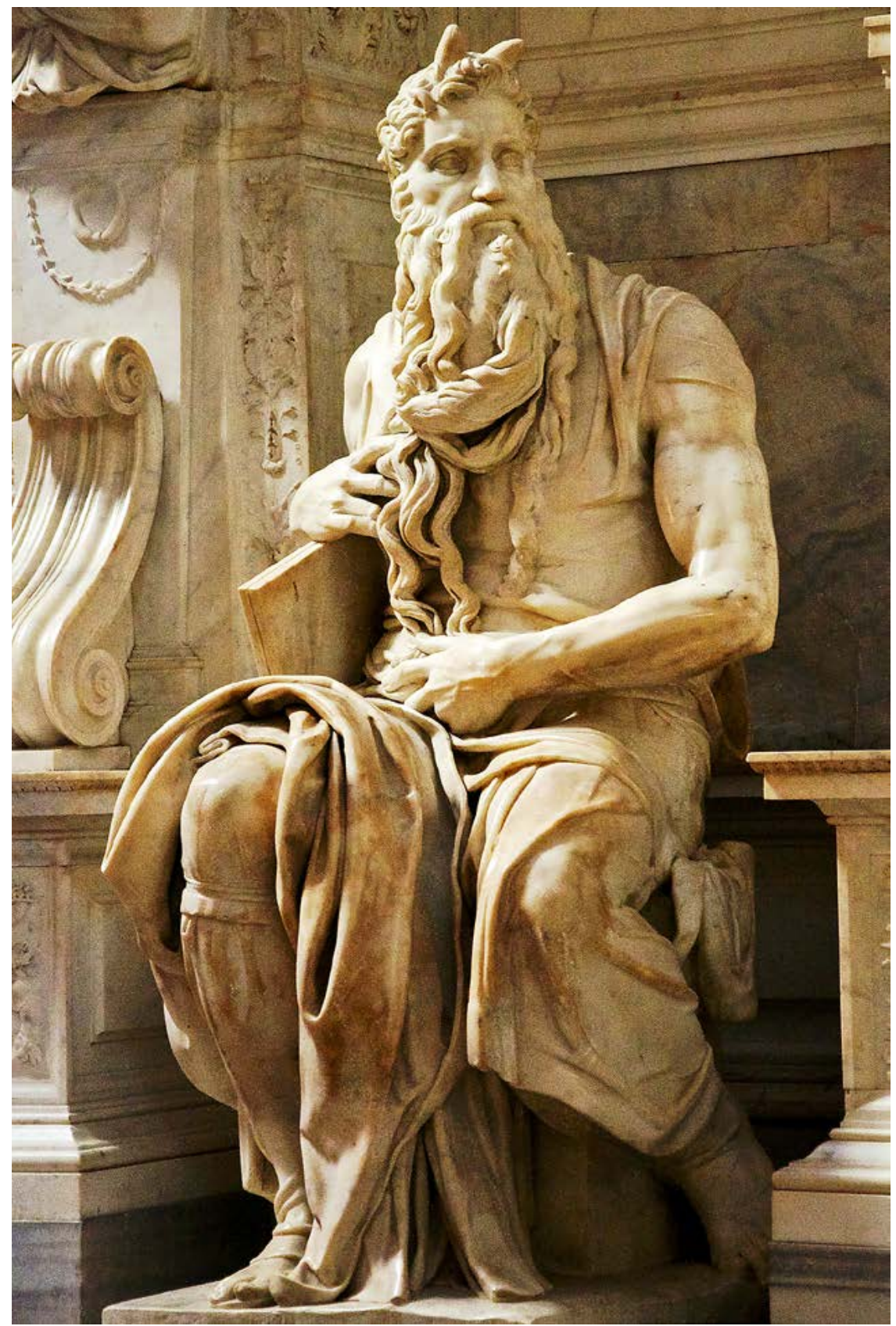

Michelangelo's Moses in the church of San Pietro in Vincoli. Photo by Luca Volpi, 2010, CC-BY-SA-3.0, Wikimedia Commons. 
- which prove that the text has been clumsily composed out of several sources (Freud 1949: 195-6).

Jones and Yerushalmi mention an inclination on the part of Freud to identify himself with Moses (Jones 1957: 394; Yerushalmi r 991: 60).

$\mathrm{He}$ also refers in Moses and Monotheism to modern exegesis, referring in the first place to an exegetical study by Ernst Sellin (Freud 2010: 59), Mose und seine Bedeutung für die israelitisch-jüdische Religionsgeschichte (1922). In the abovementioned second preface to the third part he says that his reading of this study was decisive: without it Moses and Monotheism would not have been written (Freud 2010: 95).

Sellin's thesis, so decisive for Freud, was that Moses was in fact killed by the Israelites in the desert. Sellin draws this conclusion on the basis of his study of Numbers 25 (connected to a scrutiny of Hosea 5:I), which tells of how Aaron's grandson Phineas strikes dead the chief Zimri, who has brought a Midianite woman to the Israelite camp. 'Who else than Moses possessed a Midianite wife?' Sellin asks. Zimri acts thus as a stand-in for Moses in the Biblical narrative, according to Sellin. It was in fact Moses who was stuck dead by a compatriot (Sellin I 922: 46). Given Freud's theory of the clan father being murdered by his sons (Freud 1948a: I7I), one may ask if he actually could have failed to write Moses and Monotheism, having been acquainted with a theory such as Sellin's, which he must have experienced as a more or less explicit invitation to make an application of his theory to Judaism.

There is a rumour that Sellin later abandoned his thesis, and Freud was indeed even informed about this by Abraham Shalom Yahuda in 1938. Freud answered: 'It might be true all the same.' Jones carried out investigations into the matter, but found no evidence. The rumour might, according to Jones, have emerged when Sellin at one time, "hard pressed in private talk, was willing to admit that he might have been mistaken in his interpretation of the passage in Hosea which had been the starting-point of his theory' (Jones I957: 400-I).

In his letters Freud makes comments on his work in progress. In 1937 he writes to an unknown recipient: 'I was astonished to establish that already the first, so to say embryonic experience of the people, the influence of the man Moses and the Exodus from Egypt, determined all further development until the present day - just like a real trauma of early infancy in the history of the neurotic individual' (Freud 1960: 43 I-2).

Finally he wrote to Charles Singer as the English edition of the book was being printed in 1938: 'It contains a study based on psychoanalytical assumptions concerning the origins of religion and especially the Jewish monotheism, and forms essentially a continuation and completion of another writing, which 
I published twenty-five years ago under the title "Totem and Taboo." An old man cannot think of anything new; there remains nothing else for him than to repeat himself' (Freud i 960: 445 ).

As to negative responses from the Catholic Church which Freud feared, it appears as if it was rather Jews who were against the publication. 'Jewry will feel very offended', he wrote to his son Ernst in January I 938, obviously concerning the two first parts, or one of them - unless he was referring to the manuscript of the third one, which I find unlikely, for he wrote that he had sent the treatise to him (Freud I 960: 433). In I 934 he had already expressed such a fear to Eitington: the Jews would take offence at the idea that Moses was an Egyptian (Freud and Eitington 2004: 88 I). In I 938 Freud indeed received appeals from Jews - 'a young American Jew' and Professor Yahuda - not to publish his treatise (Jones I 957: 250). In a letter of August I 9, I 939 he referred to 'the active opposition which my book Moses and Monotheism evoked in Jewish circles'(ibid. 254).

It is, in fact, easy to imagine that the resistance to Moses and Monotheism would come from Jewish circles rather than the Catholic Church or other Christian denominations, as its main target was Moses. To be sure, Freud also wanted to investigate the origins of religion on the whole, but the centrality of a figure like Moses within Judaism must nevertheless have been apt to make Jewish readers more sensitive than Christians, for whom Moses is no unquestionable authority, but rather overshadowed by Jesus Christ. Moreover, the fact that the treatise was published when antisemitism was gaining support due to national socialist influence makes it less probable that the Christian clergy would have rejected Freud's ideas about Moses especially vehemently. On the other hand, it might have increased Jewish opposition, as the questioning of Moses could be experienced as another attack in addition to those coming from the Nazis.

When Freud eventually, after his removal to London in I938, made up his mind to rework and publish the concluding part, he wrote that what might give offence and was dangerous was 'the application of my theory to the genesis of monotheism and my interpretation of religion' (Freud 2010: I64).

\section{Moses an Egyptian}

The first part of Moses and Monotheism is entitled 'Moses an Egyptian'. It opens: 'To deny a people the man whom it praises as the greatest of its sons is not a deed to be undertaken light-heartedly - especially by one belonging 
to that people. No consideration, however, will move me to set aside truth in favour of supposed national interests' (Freud 2010: I I).

Freud thus immediately addresses the ambivalence connected with the task he has taken on. While Hitler's rise to power made him more preoccupied with Judaism than hitherto, this preoccupation meant on the other hand that he directed his criticism of religion more specifically against Judaism.

Freud leaves the question open as to whether Moses really existed, but states that 'the great majority of historians have expressed the opinion that Moses did live and that the Exodus from Egypt, led by him, did in fact take place' (Freud 20IO: I I). He makes no reference to any historian, and this statement is indeed very peculiar, at least seen from a modern exegetical perspective. For biblical scholars Moses is a pre-historical figure and thus not one who can be dealt with by historians. Scholarship can only be concerned with questions pertaining to traditions referring to Moses and must relinquish aspirations to establish any historical-biographical facts about Moses as an individual.

Freud then goes on to deal with Moses' nationality, suggesting that he was in fact an Egyptian. He corroborates this with an analysis of the name Moshe, which he, referring to James H. Breasted (I 934: 350), thinks is undeniably Egyptian. While admitting that a person's name does not provide a secure conclusion about that person's nationality, he wonders why no historian has suggested that Moses was an Egyptian. 'What hindered them from doing so can only be guessed at. Perhaps the awe of Biblical tradition was insuperable.' If the question of Moses' nationality was deemed important, presenting additional material in order to answer it was welcome. This was the task of his essay; that is to say, the first part of Moses and Monotheism. The contribution it brought was, according to Freud, an application of psychoanalysis (Freud 2010: I 3-I 5).

Freud investigates the biblical story of Moses' birth and how he was abandoned by his Hebrew biological parents and rescued by the princess who brought him up as her son. He states that in tales of this kind the first family of the child, which abandons it, is a fictive one, and concludes that the Hebrew family must have been fictive, whereas the royal family is the real one. Moses was thus in fact an Egyptian, probably a noble one (Freud 2010: 22).

These arguments might not appear to be very substantial. In fact, Freud himself did not find them wholly convincing, either:

The objection is likely to be that the circumstances of the origin and transformation of legends are too obscure to allow of such a conclusion as the preceding one, and that all efforts to extract the kernel of historical truth must be doomed to failure in face of the incoherence and contradictions 
clustering around the heroic person of Moses and the unmistakable signs of tendentious distortion and stratification accumulated through many centuries. I myself do not share this negative attitude, but I am not in a position to confute it. (Freud 2010: 23-4)

If one could take the supposition seriously that Moses was an Egyptian one could, according to Freud, understand the possible motivation of the Mosaic traditions and moreover gain considerable insights about the emergence of monotheistic religions in general. At least one other fixed point is needed. An objective proof of which period Moses lived in would suffice, but Freud claims to have been unable to find any, and thinks it therefore 'better to suppress any interferences that might follow our view that Moses was an Egyptian' (Freud 2010: $24-5$ ).

This is how the first part, originally a freestanding essay in the Imago, concludes. It appears as if Freud had opened an investigation in hope of gaining new insights, realized that he was unable to corroborate his theories, which normally would have resulted in giving up publication, but nevertheless submitted the report of his fruitless efforts. As he indeed had characterized the project as his 'first performance as a historian, late enough!' one asks why he was willing to jeopardize his scholarly reputation in this way. The idea that Moses was an Egyptian obviously appeared irresistible enough to him to motivate the effort to enter the field of history, in spite of an apparent lack of evidence.

\section{If Moses was an Egyptian}

In the same year, I937, Freud nevertheless took up the thread in a second Imago essay, entitled 'If Moses was an Egyptian'. He describes his inner struggle in confronting the lack of evidence: 'The more significant the possibilities thus discerned the more cautious is one about exposing them to the critical attack of the outside world without any secure foundation - like an iron monument with feet of clay.' He also comments: 'And, lastly, it is not attractive to be classed with the scholastics and talmudists who are satisfied to exercise their ingenuity unconcerned how far removed their conclusions may be from the truth.' Then, however, he frankly states: 'Notwithstanding these misgivings, which weigh as heavily to-day as they did then, out of the conflict of my motives the decision has emerged to follow up my first essay by this contribution. But once again it is only a part of the whole, and not the most important part' (Freud 2010: 29-30).

After these introductory remarks Freud appears simply to dismiss the problem concerning the lack of evidence for Moses having been an Egyptian, and 
goes ahead with his construction based on grounds which he has just admitted to be insecure. He now points out that Moses gave the people the religion of which he became a leader, one which to this day is called Mosaic. As he was an Egyptian, this religion must be an Egyptian one. The problem is, however, that the Mosaic religion is 'a grandiosely rigid monotheism', whereas the Egyptian displayed 'a bewildering mass of deities of differing importance and provenance'. Freud made out an additional difference between the Israelite and Egyptian religions: no other people of antiquity had done so much to deny death as had the Egyptians, whereas 'the early Jewish religion ... had entirely relinquished immortality; the possibility of an existence after death was never mentioned in any place' (Freud 2010: 30-4).

Freud was right in mentioning the absence of a belief in an afterlife in Israelite religion, although it should be pointed out that it is a relative absence; a belief in a continued community with God in spite of death is also hinted at in the Hebrew Bible (see Psalm I6:IO-I I, 49:I6), and resurrection is mentioned in Isaiah 26:1 9 and Daniel I 2:2. The two latter passages belong, to be sure, to the latest strata of the Hebrew Bible, but I doubt that by 'early Jewish religion' Freud meant pre-exilic religion, which would exclude these passages. In fact, Freud himself finds the absence of an afterlife astonishing, since according to him it can well be reconciled with a monotheistic religion (Freud 20I0: 34).

Freud finds, however, a way out of the impasse created by the dissimilarity between the Egyptian and the Mosaic religions. In the nineteenth century the Pharaoh Ikhnaton (Akhenaton) had returned to our consciousness after thousands of years of oblivion, as a consequence of the excavations at Amarna. Ikhnaton proved to be a religious reformer who tried to introduce a new, monotheistic religion in Egypt - unsuccessfully, however. Theories that Israelite religion has its roots in Ikhnaton's Aton religion have exerted great influence among scholars, Freud actually being among the first to suggest a connection (Assmann 1997: 23-4). He made this connection in Moses and Monotheism. Originally his interest turned to Ikhnaton when in 1935 he read of Prince Tothmes being uncovered during the course of the excavations. He thought this might be Moses, which would prove that Moses was an Egyptian. In the following year he was informed that among the names of the pupils of the Re-Aten temple in Heliopolis built by Ikhnaton there were two which could only be interpreted as Moses and Aaron (Jones I 957: 21 I 22 I). As seen, this was nevertheless insufficient to convince him that Moses could be proved to be an Egyptian, but it gave him another clue: it helped him overcome the obstacle posed by the dissimilarity of the religions. There was thus an Egyptian religion with a strong similarity to Israelite religion. Freud also notes that Ikhnaton's 
religion says nothing about Osiris, the death god, or the realm of the dead (Freud 2010: 40-I). This could, however, be due to a lack of sources, and Jan Assmann (I 997: 254n29) points out that he was in fact wrong, but it suited his purposes well in removing one of the obstacles to the theory that the Mosaic religion was of Egyptian origin (another being the contrast between monotheism and polytheism) - the more so as the denial of death was no logical consequence of monotheism, as was pointed out by Freud. Some pages later he declares this similarity to be the first strong argument for his thesis (Freud 2010: 43).

He concludes: 'We venture now to draw the following conclusion: if Moses was an Egyptian and if he transmitted to the Jews his own religion then it was that of Ikhnaton, the Aton religion' (Freud 20 I0: 4I). He declares that this does not presuppose that Moses was a contemporary of Ikhnaton, since the Aton religion could have survived the downfall of the latter's regime in the priestly school in On, from which it originated, even if he prefers to date the Exodus in the period immediately after Ikhnaton's death (ibid. 50-2).

Freud thus retains the reservation that he has not been able to prove that Moses was an Egyptian, and also the transmission of his own religion remains a mere hypothesis. He thus openheartedly admits that his theories about a connection between the Aton religion and Israelite religion are not built on any solid basis - 'like an iron monument with feet of clay'. This is somewhat paradoxical, since he in fact has the merit of being among the first to point out the striking parallels between the two religions, an observation which is by no means to be deemed unworthy of attention, even if no solid conclusions concerning the origins of Israelite religion can be drawn from it. Apparently Freud's main interest was the person of Moses. He was aiming at psychoanalytical insights about religion connected with a powerful figure from the past, and observations on the proximity between these two religions did not offer any basis for such.

Freud nevertheless effects a comparison of the Aton and Israelite religions. He admits that the sources concerning the former are scarce, but also states: 'The Mosaic religion we know only in its final form as it was fixed by Jewish priests in the time after the Exile about 800 years later', which mirrors some degree of ignorance concerning religious and Biblical studies. He then makes the suggestion that Aton and Adonai might be connected (passing over the fact that the basic form of the latter indeed reads 'Adon'), but himself admits: 'probably we had better not make things so simple' (Freud 2010: 4I-2).

Freud makes a digression from the Aton religion, taking up the question of circumcision. He asserts that the Jews could only have learned the practice from 
the Egyptians, and then concludes that if Moses had imposed such an obligation upon them, he was no Jew but an Egyptian (Freud 2010: 44-6). Moses is also said to have been 'slow of speech' and in need of a spokesman, which Freud takes as a further proof that he was an Egyptian: he could not address the Hebrews in their language (ibid. 53-4).

Then he goes on to refer to Eduard Meyer, who in Die Israeliten und ibre Nacbbarstämme (1 906) postulates that Israelite religion has its origins in Qades and Midian. The Moses of this religion 'to whom tradition could even ascribe the erection of a brazen serpent as a healing god' differs according to Freud radically from the Egyptian 'who disclosed to his people a religion in which all magic and sorcery were most strictly abhorred'. He concludes: 'Our Egyptian Moses differs perhaps no less from the Midian Moses than the universal god Aton differed from the demon Jahve on his divine mountain.'This would for the second time refute his suggestion that Moses was an Egyptian. Now he finds an unexpected solution in Sellin's interpretation according to which the religion introduced by Moses was abandoned after he had been killed (Sellin I 922: 52 ). He does 'naturally' not consider himself in a position to decide whether Sellin's interpretation is correct, but continues: 'If he is right...' Sellin's theory 'allows us to spin our thread further without contradicting the trustworthy results of historical research' (Freud 2010: 55-60).

The next step in Freud's exposition assumes that only a fraction of the Israelites had experienced slavery in Egypt; that is the Exodus group joined with related tribes somewhere between Egypt and Canaan, during which process a new religion common to both, the Jahve religion, was adopted. Then his line of thought involves the tribe of Levi. The Israelite priests were Levites, and only they were allowed to be priests. He postulates that they were a group of Egyptians who accompanied Moses when he joined the Israelites and became their leader. A good number of these people of Moses might have survived the catastrophe which befell their leader. They grew in number and fused with the people, retaining the tradition of his teaching. 'At the time of the union with the followers of Jahve they formed an influential minority, culturally superior to the rest' (Freud 2010: 60-3).

The Jahve religion was connected with the volcanic Mount Sinai or Horeb. Its mediators were, in Freud's line of thinking, originally Midianite priests, but in the fusion of the two groups' religions Moses was allowed to take their place, or the founder of the Jahve religion, the son-in-law of Jethro, was conflated with the figure of Moses. Freud suggested that some contradictory descriptions of Moses' character as, on the one hand hot-tempered and even violent, but on the other the most patient and sweet-tempered of all men could be traced back 
to the fact that 'he' was originally two different people. Another element of the Egyptian group's religion which was retained was the practice of circumcision (Freud 2010: 66-7).

The suggestion of there originally being two figures appears to have been inspired by Sellin's theory of two different traditions of Moses (Sellin I922: 5-6). However, Freud goes one step further in postulating these two discrete figures.

Ultimately Freud states that in the 800 years between the Exodus and the fixation of the biblical text 'the religion of Jahve had followed a retrograde development that had culminated in a fusion (perhaps to the point of actual identity) with the original religion of Moses' (Freud 2010: 75). He describes the original Jahve as 'probably in no way a remarkable being. A rude, narrowminded local god, violent and blood-thirsty...' and states: 'It is truly astonishing that in spite of all the revisions in the Biblical text so much was allowed to stand whereby we may recognize his original nature'. It is even questionable whether the Jahve religion represented a true monotheism that denied the divine nature of the other nations' divinities. However, Moses had given to some of the people another and more spiritual conception of God. This tradition remained and its influence reached - though only slowly, in the course of centuries - the aim that was denied to Moses himself', Freud states. 'None can doubt that it was only the idea of this other God that enabled the people of Israel to surmount all their hardships and to survive until our time.'He now returns to the Levites, who had become one with the people or the priesthood and had developed and supervised the ritual, besides caring for the holy texts. 'But was not all this sacrifice and ceremonial at bottom only magic and black art, such as the old doctrine of Moses had unconditionally condemned?' Freud asks, and declares:

There arose from the midst of the people an unending succession of men, not necessarily descended from Moses' people, but seized by the great and powerful tradition which had gradually grown in darkness, and it was these men, the prophets, who sedulously preached the old Mosaic doctrine: the Deity spurns sacrifice and ceremonial; he demands only belief and a life of truth and justice (Maat). The efforts of the prophets met with enduring success; the doctrines with which they re-established the old belief became the permanent content of the Jewish religion. It is honour enough for the Jewish people that it has kept alive such a tradition and produced men who lent it their voice - even if the stimulus had first come from outside, from a great stranger (Freud 2010: 80-3). 
Maat, or Ma'at, was the Egyptian term for 'truth' or 'justice', and also the goddess of order. Freud notes that Ikhnaton gloried in his 'life in Maat' (Freud 2010: 96).

Freud's observations concerning the violent and bloodthirsty nature of Israelite religion, or the superior character of the prophets, are by no means unique or new, and may have been inspired by Sellin (I922: 52-4, I25). The same pertains to his questioning of the Jahve religion as true monotheism. In fact, genuine monotheism comes to expression as late as in the oracles of Second Isaiah (6th century вСE). He claims that this spiritual religion, which existed in the beginning, eventually became the dominant characteristic of the Jewish religion. The distinction Freud describes is in fact that between Israelite religion and rabbinic Judaism. Possibly he did not distinguish between them; but he had nevertheless observed the actuality of two forms of religion correctly (notwithstanding the idea of the pre-existence of Judaism in pre-historic times). On this point Freud disagrees with Sellin who concluded his book by asserting that Moses was never understood by his people and was too great for them, the word he and the prophets preached having experienced a new resurrection in the Gospel (Sellin I 922: I 54-6). Sellin apparently did not recognize that rabbinic Judaism carried on the spirit of the word preached by Moses and the prophets, mirroring anti-Judaist attitudes of previous Christian theology.

The impression given of the Aton religion is indeed one of such a spiritual religion, and provided that there is a connection with the religion of Moses, one is of course tempted to imagine that the latter was of the same kind. Nevertheless, at least two obstacles remain: due to the scarcity of sources our knowledge of the Aton religion is very tentative, and its connection with Israelite monotheism remains an intriguing hypothesis. To be sure, in the concluding part of Moses and Monotheism, to be dealt with below, Freud points out that 'a spontaneous development to a higher spirituality during a cultural life extending over many centuries' did not lead to monotheism amongst the Greek people. In Egypt monotheism emerged as a side effect of imperialism: God mirrored the almighty Pharaoh. For the tiny Jewish people there was no reason to think that their God would rule over the world, ergo they must have taken over this idea from an external source; that is, Egypt. (Freud 2010: 105)

Freud's comment on sacrifice is also interesting, reflecting a Jewish view, advocated by, for example, Moses Maimonides in The Guide for the Perplexed $(3: 32)$.

It is significant that Freud ascribes circumcision to the Egyptian Moses, and thus considers it a component of his religion of truth and justice, since it is also a component of Judaism, unlike sacrifice. Provided his view that Israelite 
traditions could emanate either from the Egyptian Moses or his Midianite counterpart it is clear that circumcision could only stem from the former. It is nevertheless noteworthy that Freud did not come upon the idea to dismiss it as an unspiritual tradition - an additional indication that Freud was inclined to retroject rabbinic Judaism into the earliest stages of Israelite religion.

Another reflection which can be made is that Freud seems to have put aside his critical attitude towards religion. There is no mention in the conclusion of this second essay of religious phenomena being 'only on the model of the neurotic symptoms of the individual'. Instead, he uses words like 'honour enough for the Jewish people' and 'kept alive such a tradition' the stimulus of which came 'from a great stranger'.

\section{Moses, his people and monotheistic religion}

In the conclusion, which Freud at first thought he would no longer be able to accomplish (Freud 2010: 85), he suggests that in the first phase of the scribal record of the Israelite religious traditions the material pertaining to Moses' religion was deleted or altered, but preserved in an oral report. However, the oral report did not diminish as time passed, but rather found its way into later codifications of the official accounts. This is, according to Freud, not a familiar conception, but he thinks that some analogies can be found. He refers to national epics among the Greeks, but also among the Germans, Indians and Finns. Times in the remote past have a great attraction for the imagination. 'As often as mankind is dissatisfied with its present ... it harks back to the past and hopes at last to win belief in the never-forgotten dream of a Golden Age.' Nevertheless, religion was reproduced with a faithfulness for which the epic cannot provide a parallel, and therefore a better parallel is to be searched for, Freud concludes (Ibid. I Io-I6).

Freud then repeats what he stated in Totem and Taboo: that the primitive humans lived in hordes where the father took possession of all females and either slew, castrated or drove away his sons. Eventually the sons came together, slew the father and devoured him in a ritual banquet. All subsequent generations bear the reminiscence of this event in their mind (the archaic heritage, reminiscent of Jung's collective unconscious, which Freud, however, did not find useful; Freud 2010: I 57, 208), and this also plays a decisive role in the emergence of religion, as can be demonstrated by the Christian Eucharist. The Jews were particularly influenced by this primeval incident, since the slaying of Moses in the desert was strongly reminiscent of it. Then Freud declares that 'Paul, a Roman Jew from Tarsus, seized upon this feeling of guilt and correctly traced it back 
to its primæval source'. In Paul's interpretation, according to Freud, the death of Moses was expiated through the death of Christ. Through its universality Christianity reinstated one characteristic of the Aton religion, but on the other hand, Freud thinks, contrary to Sellin, it was a cultural regression compared to Judaism. 'Christian religion did not keep to the lofty heights of spirituality to which the Jewish religion had soared'. It was

...no longer strictly monotheistic, took over from the surrounding peoples numerous symbolical rites, reestablished the great Mother Goddess and found room for many deities of polytheism in an easily recognizable disguise - though in subordinate positions. Above all it was not inaccessible as the Aton religion and the subsequent Mosaic religion had been - to the penetration of superstitions, magical and mystical elements which proved a great hindrance to the spiritual development of two following millenia. (Freud 2010: I30-42)

Freud draws a parallel between this regression and the downfall of the Aton religion (Freud 2010: 2 I 4 ).

In this context Freud also addresses antisemitism. He lists some deeper motives which come from the unconscious of the nations: the jealousy evoked by the Jews in claiming to be the first-born, favourite child of God; circumcision, which reminds people of the dreaded castration; and, finally, the people excelling in antisemitism became themselves Christians relatively late. 'They have not yet overcome their grudge against the new religion which was forced on them, and they have projected it on to the source from which Christianity came to them.... The hatred for Judaism is at bottom hatred for Christianity, and it is not surprising that in the German National-Socialist revolution this close connection of the two monotheistic religions finds such clear expression in the hostile treatment of both' (Freud 2010: 147-8).

Among these motives of antisemitism two are thus religious, and the third one is also connected to a religious rite, one which in Freud's view was instigated by Moses. The Nazi antisemitism of his day was, however, founded on outspokenly non-religious ideas. Hitler criticized the Christian social party founded by Karl Lueger for not building its antisemitism on racial but on religious grounds (Hitler I94I: I30-I). Freud seems to have linked Jewishness with Judaism as religion, thus addressing rather anti-Judaism than antisemitism (to be sure, this distinction remains rather vague).

In the section 'The Progress in Spirituality' Freud deals with some elements of Judaism. As to the prohibition of images in Israelite religion, he thinks that 
Moses had not taken this over from the Aton religion. Rather, he surpassed it in his 'strictness'. He thinks this commandment has more significance than is at first obvious. 'If this prohibition was accepted, however, it was bound to exercise a profound influence. For it signified subordinating sense perception to an abstract idea; it was a triumph of spirituality over the senses; more precisely an instinctual renunciation accompanied by its psychologically necessary consequences' (Freud 2010: I78-9).

This commandment raised God to a higher level of spirituality. The dematerializing of God resulted in the Jews appreciating their literature. Immediately after the destruction of the temple Rabbi Yochanan ben Zakkai demanded permission to establish a Torah school in Yavne. 'From now on it was the Holy Book, and the study of it, that kept the scattered people together.' The preference given by the Jews to spiritual endeavour 'has helped to build a dyke against brutality and the inclination to violence which are usually found where athletic development becomes the ideal of the people' (Freud 20I0: I8I-2). Hereby Freud explicitly connects rabbinic Judaism with a reconstruction of (the Egyptian) Moses' religion.

One asks what in the content of this piece actually was offensive, so that Freud felt he had to hold back his study for years, and which caused so many to ask him not to publish it? He said it was the application of his findings to the genesis of monotheism and his interpretation of religion. The substance of this application was that the slaying of Moses had a strong influence on the subsequent generations of Jews because of its reminiscence of a primeval incident of parricide committed by the primitive brotherhood as postulated in Totem and Taboo, and that this circumstance also played a decisive role in the emergence of Christianity. This means that no god was needed for the constitution of the Christian faith, since we are dealing with an inner-psychical procedure, albeit a collective one. Nevertheless, in the section 'The Truth of Religion', Freud writes: 'I can only regret it if certain experiences of life and observations of nature have made it impossible for me* to accept the hypothesis of such a Supreme Being. As if the world had not enough problems, we are confronted with the task of finding out how those who have faith in a Divine Being could have acquired

* $\quad$ Omitted in Katherine Jones' translation. Freud writes in the first person plural ('We can only regret...', '... have made it impossible for us to accept...'Freud I950: 23I). It is obvious that Freud refers to himself ('certain experiences of life'), and the sequel of the quotation shows that he did not think it had become generally impossible to believe. 
it, and whence this belief derives the enormous power that enables it to overwhelm Reason and Science' (Freud 2010: 194).

There is a significant contrast between the third part of Moses and Monotheism and the two first. The third part involves extensive sections on psychoanalysis with no explicit connection to Moses or Judaism. There is a remarkable lack of coherence, whereas the two first still bear the mark of the brilliant Freud. He says that he had reworked it after his resettlement in London which took place in June 1938 (Freud 2010: 164-5). He died in September 1939. In February I939 his doctors established a recurrence of cancer which they deemed inaccessible so that no further operation could be performed (Jones 1957: 256-7; Freud and Zweig 1968: I 86; Freud and Eitington 2004: 920-I). The reworking was apparently not very successful; it looks as if Freud was no longer in possession of the capacity required for writing at the qualitative level of the first instalments.

There is an apparent tendency in Moses and Monotheism to connect rabbinic Judaism with the alleged religion of Moses, which was thought to have been suppressed by inferior tendencies, but nevertheless in the course of centuries, to have survived and eventually in its turn suppressed these inferior tendencies, i.e. the Jahve religion. This thesis cannot be proved, as nothing is known about Moses as a historical person, but Freud's high esteem of rabbinic Judaism remains the essence of his ultimate legacy, Moses and Monotheism.

Risto Olavi Nurmela, Master of Theology 1986, Doctor of Theology 1996 at Åbo Akademi University. Adjunct Professor of Old Testament Exegetics from 1999. Publications on Viktor Frankl and C. G. Jung. President of the Finnish Society of Logotherapy. Viktor Frankl Award of the City of Vienna for Outstanding Achievements in the Field of Meaning-Oriented Humanistic Psychotherapy 2001.

\section{References}

Assmann, Jan, I997. Moses the Egyptian: The Memory of Egypt in Western Monotheism (Cambridge, MA, Harvard University Press)

Berkley, G. E., I 988. Vienna and Its Jerws: The Tragedy of Success 1880s-1980s (Toronto, Abt Books)

Breasted, James H., I 934. The Dawn of Conscience (New York, Charles Scibner's Sons) Cocks, Geoffrey, I 997. Psychotherapy in the Third Reich: The Göring Institute, 2nd edn (New Brunswick, Transaction Publishers)

Freud, Sigmund, I948a. Gesammelte Werke, 9. Totem und Tabu (London, Imago Publishing Co.)

— I 948b. Gesammelte Werke, I 4. Werke aus den Jahren 1925-1931 (London, Imago Publishing Co.) 
- i 949. Gesammelte Werke, Io. Werke aus den Jahren 1913-1917 (London, Imago Publishing Co.)

- I950. Gesammelte Werke, I6. Werke aus den Jahren 1932-1939 (London, Imago Publishing Co.)

- i 960. Briefe 1873-1939 (Frankfurt am Main, Fischer)

_oro. Moses and Monotheism, trans. Katherine Jones (Mansfield Centre, CT, Martino Publishing)

Freud, Sigmund, and Max Eitington, 2004. Briefwechsel 1906-1939, ed. Michael Schröter (Tübingen, Edition Diskord)

Freud, Sigmund, and Sándor Ferenczi, 2005. Briefwecbsel 3/2, 1925-33 (Wien, Böhlau)

Freud, Sigmund, and Oskar Pfister, I 963. Briefe 1909-1939 (Frankfurt am Main, Fischer)

Freud, Sigmund, and Arnold Zweig, r 968. Briefwechsel, hrsg. Ernst L. Freud (Frankfurt am Main, Fischer)

Hitler, Adolf, r 94 I. Mein Kampf (München, Zentralverlag der NSDAP)

Jones, Ernest, I957. Sigmund Freud: Life and Work, vol. 3, The Last Phase 1919-1939 (London, The Hogarth Press)

Sellin, Ernst, 1922. Mose und seine Bedeutung für die israelitisch-jüdische Religionsgeschichte (Leipzig, A. Deichertsche Verlagsbuchhandlung)

Yerushalmi, Yosef Chayim, I 99 I. Freud's Moses: Judaism Terminable and Interminable (New Haven and London, Yale University Press) 